\title{
DAMPAK PELAYARAN KAPAL LAUT DI ALUR SUNGAI MUSI
}

\author{
Sunarso Sugeng \\ Program Studi Diploma III Teknik Perkapalan \\ Fakultas Teknik Universitas Diponegoro
}

\begin{abstract}
Sunarso Sugeng, in this paper explain that the effect of movement of ship in Musi River cause environmental damage in the form of path exterior erosion / wall step aside river,effect from this material erosion result the happening of accelerateing sedimentation which enough quickly so that degrade energy support sea transport path and for the conservancy of groove this sea transport require dredging fund which do not lessen fastly of this sedimentation one of the way of is to make regulation demarcation speed of sea transport to ship have certain dimension ..

To lessen erosion effect movement of other causes and boat, earn is also considered to regarding strong effort of bank groove by protecting it with bagwark, revetment etcetera as according to principle engineer river
\end{abstract}

Key word Sungai musi

\section{PENDAHULUAN}

Sejalan dengan keberhasilan pembangunan di Propinsi Sumatera Selatan khususnya ekonomi akan berdampak pada tumbuhnya pusat-pusat kegiatan baru dan berkembangnya pusat-pusat kegiatan yang telah ada, hal ini akan menyebabkan mobilitas angkutan orang dan angkutan barang.

Sungai Musi sebagai prasarana utama transportasi air di wilayah Propinsi Sumatera Selatan adalah salah satu unsur yang harus diperhatikan perkembangan pembangunan di wilayah tersebut terutama dalam aktivitas pendistribusian barang melalui jalur sungai.

Peranan tersebut lebih berarti pada masa sekarang di mana Sungai Musi telah menjadi jalur transportasi yang sangat penting, terutama bagi alur pelayaran angkutan laut yang membentang sejauh \pm 111,12 km dari Pelabuhan Palembang sampai dengan Muara Sungai (ambang luar).

Disisi lain, dengan dilayari Sungai Musi oleh kapal laut ternyata menimbulkan masalah tersendiri. Hal tersebut terkait dengan sifat sungai ini sebagai alur pelayaran perairan daratan yang memiliki berbagai keterbatasan dalam beberapa hal, seperti kedalaman dan kelebaran alur serta kecepatan kritis material pembentuk alur. Masalah tersebut akan terjadi apabila kapal laut dalam proses navigasinya tidak memperhatikan berbagai keterbatasan tersebut, terutama dalam aspek kecepatan berlayar, sehingga dapat menyebabkan timbulnya kerusakan alur. Kerusakan tersebut berupa penggerusan tepi dan dasar alur yang selanjutnya akan menimbulkan proses sedimentasi sehingga dapat menyebabkan pendangkalan alur yang berpengaruh terhadap aspek keselamatan pelayaran.

Hal ini menyebabkan terbatasnya karakteristik kapal yang dapat berlayar pada alur tersebut. Adapun penyebab terjadinya pendangkalan tersebut disinyalir oleh beberapa pihak adalah berasal dari lereng pegunungan sebelah hulu, daratan pinggir sungai serta sedimen dari erosi tebing dan dasar alur. Erosi pada alur tersebut terjadi dikarenakan oleh pergerakan kapal sebagai faktor utama di samping karena faktor alam lainnya seperti pengaruh pasang surut.Kenyataan di lapangan menunjukan bahwa besarnya gelombang yang dihasilkan oleh kapal, terutama kapal laut dengan dimensi yang relatif besar saat melintasi alur. Selain itu, kerusakan sungai ini diperkirakan terjadi secara intensif seiring dengan makin ramainya arus lalu lintas kapal laut.

\section{TUJUAN PENULISAN}

Adapun tujuan penulisan ini adalah:

- Untuk mengetahui kondisi dan gambaran sebenarnya mengenai keberadaan kapal laut dan pengaruhnya pada alur pelayaran Sungai Musi.

- Untuk memberikan sumbangan pemikiran bagi masalah perawatan alur pelayaran Sungai Musi.

\section{RUANG LINGKUP KAJIAN}

Sungai Musi sebagai prasarana utama angkutan sungai di Sumatera Selatan, khususnya Kota Palembang, memiliki panjang total yang dapat dilayari $\pm 450 \mathrm{~km}$, membelah Provinsi Sumatera Selatan dari Timur ke Barat. Bila ditelusuri dari bagian hulu (Barat) ke hilir sampai ke Kota Palembang, Sungai Musi ini bercabang-cabang dengan 8 anak sungai yang cukup besar. Kedalaman Sungai Musi bervariasi antara 4,5 m 25 meter, yang diakibatkan oleh pengaruh sedimentasi yang cukup tinggi karena adanya arus pasang dengan kecepatan maksimum 0,6 knot arah Selatan dan 2,3 knot arah Utara sedangkan kondisi pasang-surut di perairan Sungai Musi adalah sebagai berikut : 
- $\quad$ Air Tertinggi

$: 4,10$ LWS
$: 3,70$ LWS
$: 2,05$ LWS
$: 0,50$ LWS

- Duduk Tengah

: 0,50 LWS

dengan waktu Air Tinggi (AT) di pelabuhan 4 jam lebih lambat dari waktu AT daerah ambang luar Sungai Musi, beberapa variabel yang mempengaruhi suatu alur pelayaran untuk kapal kapal tertentu harus memenuhi beberapa persyaratan yaitu, adanya kesesuaian antara kapal dengan alur pelayaran seperti : panjang kapal, lebar kapal, draft kapal, kecepatan kapal, lebar alur, kedalaman alur dan kecepatan arus air pada alur.

\section{ANGKUTAN LAUT}

Perkembangan lalu lintas kapal pada alur pelayaran Sungai Musi dipresentasikan pada Tabel.1.

Dari Tabel.1 tersebut dapat ditunjukkan bahwa kapal dengan ukuran sarat air antara 3,1 meter sampai 5,0 meter paling banyak melewati alur pelayaran Sungai Musi dengan jumlah 1.605 kapal dan berdasarkan pengamatan didominasi kapal jenis Cargo Vessels.

Untuk alur pelayaran ambang luar Sungai Musi dimensi alur perawatannya adalah dengan kelebaran dasar alur 120 meter, kedalaman 6,5 m LWS dan kemiringan alur 1:4. Kondisi penampang melintangnya dapat dilihat pada Gambar 1.

Sepanjang alur pelayaran Sungai Musi terdapat kedalaman dan kelebaran yang bermacam - macam, daerah yang paling dangkal adalah pada bagian ke arah laut atau mulut sungai. Sesuai dengan kondisi alamiah Sungai Musi ternyata kedalamannya bervariasi antara 4,5 meter sampai 25 meter. Oleh karena itu ada beberapa daerah yang ditetapkan sebagai daerah rawan untuk pelayaran yaitu kedalamannya dibawah 6 meter LWS dan terjadi akibat sedimentasi. Pengerukan pemeliharaan dilakukan secara periodik setiap tahunnya. Kedalaman alur pelayaran bervariasi dari hari ke hari dan bersamaan waktunya dengan kondisi pasang surut muka air.Fenomena pasang surut pada Sungai Musi diukur pada daerah ambang luar pelayaran. Berikut data pasang surut seperti tertera pada Tabel 2.

\section{ANALISIS}

\section{Penampang Melintang Alur}

Tabel 3. menampilkan data penampang melintang alur pelayaran Sungai Musi pada salah satu lokasikritis sedimentasi yaitu di lokasi "Payung Selatan" data dari PT. (Persero) Rukindo Unit Usaha Palembang yang dijadikan bahan kajian pada penulisan ini.

Pada setiap lokasi alur pelayaran Sungai Musi terdapat jenis material pembentuk alur yang berbeda - beda. Material - material tersebut merupakan material sedimentasi yang dibawa dari hulu, termasuk juga sampah - sampah dari pemukiman atau dari tanaman - tanaman yang hanyut dari hulu seperti enceng gondok dan kemudian membusuk lalu tenggelam. Namun secara garis besar yang terbanyak dapat dibagi menjadi 2 jenis material yaitu lumpur dan pasir. Tabel 4 menunjukkan jenis material pembentuk alur pelayaran Sungai Musi.

Dari data tersebut dapat diketahui bahwa jenis material pembentuk alur pelayaran sungai pada lokasi Payung Selatan yaitu pasir bercampur lumpur dan berdasarkan teori hidrolika dalam buku "Hidrolika Saluran Terbuka" dijelaskan jenis material tersebut memiliki kecepatan kritis sebesar $2,5 \mathrm{ft} / \mathrm{s}$ atau $0,762 \mathrm{~m} / \mathrm{det}$, dengan diameter (Dn) dan densitas relatif material $(\Delta)$ menurut ESCAP sebesar 0,4 $\mathrm{mm}$ dan 0,2.mm.Sedangan jarak dari ambang luar ke Pelabuhan Boom Baru Palembang adalah $111,12 \mathrm{~km}$ dengan waktu tempuh pelayaran adalah selama 6 jam. kecepatan rata - rata kapal yang berlayar di alur pelayaran Sungai Musi adalah sebagai berikut:

$$
\begin{aligned}
\mathrm{V} & =\mathrm{s} / \mathrm{t} \\
& =111,12 \mathrm{~km} / 6 \mathrm{jam} \\
& =18,52 \mathrm{Km} / \mathrm{Jam}(1 \mathrm{knot}=1,852 \mathrm{~km} / \mathrm{jam}) \\
& =10 \mathrm{Knot} \\
& =5,144 \mathrm{~m} / \mathrm{det}
\end{aligned}
$$

\section{Analisis Kesetabilan Alur}

Perhitungan kondisi alur dapat kita hitung dengan rumus:

$\Delta \mathrm{V}^{\wedge}+\mathrm{u} \leq \mathrm{V}_{\mathrm{cr}}$

$\mathrm{Cw} \times \Delta \mathrm{x} \mathrm{Dm} \geq(\mathrm{H}=\mathrm{Z} \max )$

Hasil perhitungan dengan metode tray and error seperti tersaji pada Tabel.6.

Tabel 6. Perhitungan Nilai $\Delta$ h penampang bagian kiri

\begin{tabular}{ccc}
\hline $\begin{array}{c}\Delta \mathrm{h}_{\mathrm{l}}(\mathrm{m}) \\
\text { coba-coba }\end{array}$ & $\mathrm{Ac}_{\mathrm{l}} / \mathrm{Aw}_{\mathrm{l}}$ & $\Delta \mathrm{h}_{\mathrm{l}}(\mathrm{m})$ akhir \\
\hline 0 & 1,032 & 0,091 \\
0,091 & 1,043 & 0,121 \\
0,121 & 1,046 & 0,131 \\
0,131 & 1,047 & 0,134 \\
0,134 & 1,048 & 0,135 \\
0,135 & 1,048 & 0,135 \\
\hline
\end{tabular}

Sumber : Hasil Analisis

Tabel 7 adalah hasil perhitugan alur sebelah kanan.

Tabel 7. Perhitungan Nilai $\Delta \mathrm{h}$ penampang bagian kanan

\begin{tabular}{ccc}
\hline $\begin{array}{c}\Delta \mathrm{h}_{\mathrm{r}}(\mathrm{m}) \\
\text { coba-coba }\end{array}$ & $\mathrm{Ac}_{\mathrm{r}} / \mathrm{Aw}_{\mathrm{r}}$ & $\Delta \mathrm{h}_{\mathrm{r}}(\mathrm{m})$ akhir \\
\hline 0 & 1,031 & 0,084 \\
0,084 & 1,0397 & 0,109 \\
0,109 & 1,0424 & 0,117 \\
0,117 & 1,0433 & 0,119 \\
0,119 & 1,0435 & 0,120 \\
0,120 & 1,0436 & 0,120 \\
\hline
\end{tabular}

Sumber: Hasil Analisis 
Dari nilai tersebut setelah kita hitung kesetabilan alur sebelah kiri bedasarkan Persaman $\mathbf{1}$ dan $\mathbf{2}$ didapatkan besarnya nilai $\mathrm{H}$.

$$
\mathrm{H}=2,372 \times 0,4 \times 0,2=0,190 \mathrm{~m}
$$

$\mathrm{H} \geq \mathrm{Z} \max \geq 1,5 \times \Delta \hat{\mathrm{h}}_{1}$ atau $\mathrm{H} \geq 0,127 \mathrm{~m}$ didapatkan juga nilai :

$\Delta \mathrm{V}_{1}$ sebesar $0,286 \mathrm{~m} / \mathrm{s}$ lebih besar dari $0,222 \mathrm{~m} / \mathrm{s}$ dan nilai $\Delta \hat{h}_{1}$ sebesar $0,152 \mathrm{~m}$, lebih besar dari $0,127 \mathrm{~m}$, maka "alur tergolong tidak stabil" kondisi ini dipastikan akan terjadi erosi akibat pergerakan kapal.

Dengan cara yang sama kita hitung kesetabilan alur sebelah kanan dan didapatkan nilai $\Delta V_{1}$ sebesar 0,295 lebih besar dari $0,222 \mathrm{~m} / \mathrm{s}$ dan nilai $\Delta \hat{h}^{\hat{1}}$ sebesar $0,162 \mathrm{~m}$ lebih besar dari 0,127 m, maka "alur tergolong tidak stabil" dengan kondisi ini dipastikan juga akan terjadi erosi akibat pergerakan kapal yang melewati alur tersebut.

\section{Analisis Data Tinggi Air}

Data variasi tinggi muka air atau pasang surut pada alur pelayaran Sungai Musi diukur di ambang luar alur pelayaran Sungai Musi karena pengukuran tersebut didasarkan atas titik terendah posisi muka air laut terendah, kemudian titik tersebut dijadikan titik $0 \mathrm{~m}$ LWS.

Untuk menentukan kedalaman rata-rata yang dapat dipergunakan untuk pelayaran didasarkan kepada kurva waktu - kedalaman (depth-duration curve). Kurva waktu kedalaman ini dapat dihitung berdasarkan data hidrografi pasang surut per tahun dan disajikan pada Tabel.8

Rekapitulasi variasi tinggi muka air tahun 2007 pada alur pelayaran sungai musi berdasarkan jumlah data pada setiap tinggi air per tahunnya :

Dari data tersebut kita buat gambar Grafik Kurva Durasi kedalaman alur sungai seperti tersaji pada Gambar.2.

Dari kurva durasi tersebut dapat ditentukan bahwa nilai HHWL (High Highest Water Level) sebesar $40 \mathrm{dm}$ dan nilai LLWL (Low Lowest Water Level) sebesar $1 \mathrm{dm}$. Selanjutnya menurut Modul Teknologi Alur Pelayaran Balai Diklat LLASDP untuk menghitung besar kedalaman yang dapat dilayari ialah dengan menggunakan rumus :

$$
h_{\text {rata }- \text { rata }}=h_{\min }+\left(\frac{A}{T}\right) Z
$$

Keterangan :

$$
\begin{aligned}
\mathrm{A}= & \text { luas bidang pada kurva kedalaman } \\
& \text { waktu yang dibatasi oleh kedalaman } \\
& \text { maksimum dan kedalaman minimum } \\
\mathrm{T}= & \text { jumlah waktu yang diambil dalam } \\
& \text { perhitungan } \mathrm{A} \\
\mathrm{Z}= & \text { konstanta untuk memperhitungkan } \\
& \text { faktor keamanan yang besarnya antara } \\
& 0,7-0,9
\end{aligned}
$$

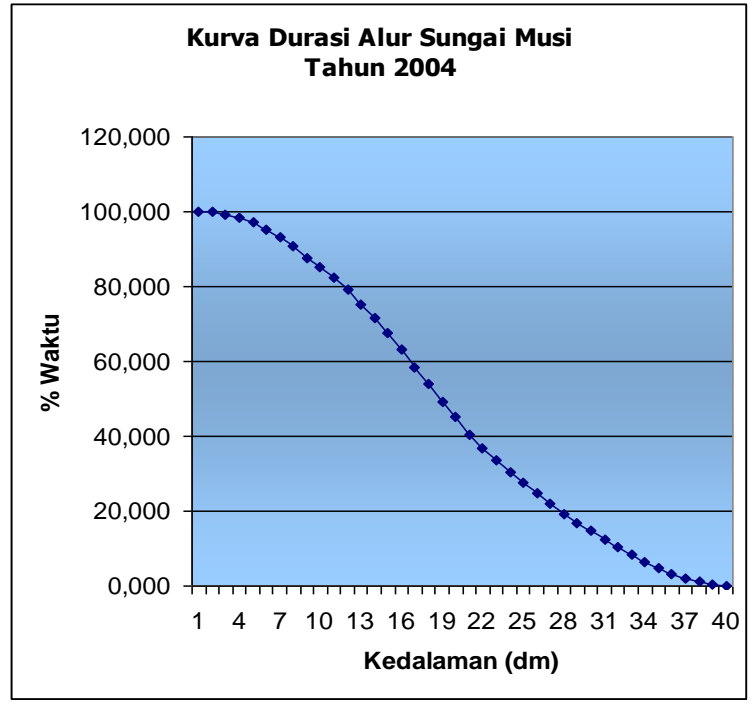

Gambar.2. Kurva Durasi Alur Sungai Musi Tahun 2007 Sumber : Dinas Perhubungan Kota Palembang

Hasil perhitungan pengaruh ukuran kapal dan kecepatan kapal terhadap kedalaman rata-rata muka air serta kecepatan arus balik disajikan pada Tabel 9.

\section{Analisis Lalu Lintas Kapal (Wp)}

Berdasarkan data kunjungan kapal di Pelabuhan Boom Baru Palembang dari tahun 1999 sampai dengan 2004 yang tertera pada tabel II.7 maka dapat diperhitungkan volume lalu lintas kapal dari berbagai jenis per tahun di alur pelayaran Sungai Musi sebesar :

$$
\begin{aligned}
\text { LLK } & =\frac{V 1999+V 2000+V 2001+V 2002+V 2003+V 2004}{\text { Jumlahtahun }} \\
& =\frac{3.548+4.071+3.767+3.651+3.655+4.030}{6} \\
& =3.787 \text { kapal per }- \text { tahun } \\
& =0,431 \text { kapal per-jam. }
\end{aligned}
$$

Menurut ketetapan yang dikeluarkan oleh PIANC bekerjasama dengan IAPH (Internasional Association Ports and Harbor), IMPA (International Maritime Pilots Association) dan IALA (International Association of Lighthouse Authority) bahwa terdapat kategori yang menunjukkan tingkat keramaian pada suatu alur pelayaran ditunjukkan seperti pada Tabel 10.

Tabel 10. Tingkat Keramaian Lalu Lintas Kapal

\begin{tabular}{|c|c|}
\hline Ringan & Keramajan Kapal perjam \\
Sedang & $0-1$ \\
Normal & $>1-3$ \\
\hdashline & $>3$ \\
\hline
\end{tabular}

Sumber : PIANC, IAPH, IMPA, IALA 
Sehingga dapat disimpulkan bahwa tingkat keramaian lalu lintas kapal di alur pelayaran Sungai Musi masih tergolong kategori ringan (rendah). Oleh karena itu penambahan lebar alur $=0 \mathrm{~B}$.

\section{Analisis Jarak Kapal Pada Dinding Alur (Wbr}

Penentuan jarak antara kapal dengan dinding alur amat penting mengingat fenomena banksuction yang berpotensi untuk menggeruskan dinding alur pelayaran. pada alur pelayaran dengan sisi miring yang dilewati oleh kapal dengan kecepatan kapal yang sedang maka penambahan lebar adalah sebesar $0,5 \mathrm{~B}$.

Sesuai dengan rumus (2) maka lebar sebenarnya untuk alur pelayaran payung selatan yang aman dan sesuai dengan dimensi kapal yang sering melewati alur pelayaran Sungai Musi adalah:

$$
\begin{aligned}
& W=2 W b m+2 \sum_{i=1}^{n} W i+2 W b r+\sum W p \\
& W=2(1,5 B)+2(0,4 B+0,0 B+0,7 B+0,1 B) \\
& W=2(1,5 B)+2(0,4 B+0,0 B+0,7 B+0,1 B) \\
& W=8 B
\end{aligned}
$$

Untuk kedalaman rencananya tidak berubah yaitu 6,5 meter LWS.

Gambar 3 merupakan penampang melintang alur pelayaran yang aman dan sesuai dengan dimensi kapal yang lewat pada alur pelayaran Sungai Musi Palembang. Berdasarkan data sarat air kapal yang ada pada tabel .2,kapal terbanyak yang melewati alur pelayaran adalah yang memiliki draft antara 3,1 - 5,0 meter dan draft tertinggi mencapai 9,0 meter. Untuk itu 2 alternatif pilihan dalam menentukan dimensi alur pelayaran yang aman dan sesuai dengan dimensi kapal yang melintasinya, yaitu :

\section{- Alternatif I}

Untuk alternatif I sebagai berikut :

$$
\begin{array}{lll}
\circ & \text { draft kapal (d) } & : 5,0 \text { meter } \\
\circ & \text { Lebar kapal (B) } & : 12,7 \text { meter } \\
\circ & \text { Panjang Kapal (LOA) } & : \text { meter }
\end{array}
$$

Jadi, lebar dasar alur pelayaran yang aman dan sesuai adalah sebesar $8 \mathrm{~B}=8(12,7$ meter $)=$ 101,6 meter. Gambar 4 merupakan gambar penampang melintang. Dari gambar tersebut dapat diketahui bahwa berdasarkan ketentuan ketentuan yang dikeluarkan oleh PIANC mengenai perancangan suatu alur pelayaran dimensi alur pelayaran Sungai Musi pada lokasi payung selatan belum sesuai dengan dimensi kapal yang sering melintasi alur pelayaran tersebut, dengan kelebaran alur perawatan yang hanya 100 meter sehingga dikhawatirkan terjadi tabrakan apabila ada 2 buah kapal yang berlayar berlintasan pada lokasi tersebut. Untuk itu diperlukan penambahan lebar dasar alur pelayaran sebesar : 101,6 meter -100 meter $=1,6$ meter

- $\quad$ Alternatif II

Untuk alternatif II sebagai berikut :
○ draft kapal (d)

$\begin{array}{lll}\circ & \text { Lebar kapal (B) : } & 22,3 \text { meter } \\ \text { ○ } & \text { Panjang Kapal (LOA) : } & 153 \text { meter }\end{array}$

Jadi, lebar dasar alur pelayaran yang aman dan sesuai adalah sebesar $8 \mathrm{~B}=(8 \times 22,3$ meter $)=$ 178,4 meter. Gambar 5 merupakan penampang melintangnya.

Sesuai ketentuan PIANC, dimensi alur pelayaran sungai musi pada lokasi payung selatan belum sesuai dengan kapal yang memiliki dimensi LOA=153 $\mathrm{m}, \mathrm{B}=22,3 \mathrm{~m}$ dan $\mathrm{D}=9 \mathrm{~m}$ untuk melintasi alur pelayaran tersebut, dengan kelebaran alur perawatan yang hanya 100 meter dikhawatirkan terjadi tabrakan apabila ada 2 buah kapal yang berlayar berlintasan pada lokasi tersebut. Untuk itu diperlukan penambahan lebar dasar alur pelayaran sebesar : 178,4 meter -100 meter $=78,4$ meter.

\section{KESIMPULAN}

Dari hasil kajian perawatan alur Pelayaran Sungai Musi dapat kami simpulkan sebagai berikut:

- Alternatif I

Dalam alternatif I ini diperlukan penambahan lebar dasar alur pelayaran sebesar 1,6 meter dari lebar alur perawatan yang ada sehingga kapal - kapal dengan draft sampai 5,0 meter yang merupakan lalu lintas kapal terbanyak dapat berlayar dengan aman. Untuk kapal dengan draft diatas 5 meter tidak dapat masuk ke ambang dalam alur pelayaran dan dapat berlabuh di ambang luar, sehingga membutuhkan kapal - kapal kecil untuk mengangkut barang yang dibongkar di muara sungai tersebut menuju pelabuhan.

- Alternatif II

Dalam alternatif II ini diperlukan penambahan lebar dasar alur pelayaran sebesar 78,4 meter dari lebar alur perawatan yang ada sehingga kapal - kapal dengan draft sampai 9,0 meter yang merupakan draft kapal terbesar yang masuk ke alur pelayaran sungai musi dapat berlayar dengan aman. Tetapi tentu saja biaya yang harus dikeluarkan untuk pengerukan pemeliharaan akan bertambah besar seiring dengan bertambahnya kelebaran dasar alur pelayaran yang akan dikeruk.

\section{DAFTAR PUSTAKA}

1. Bambang Triatmodjo, 1996, Pelabuhan, Beta Offset, Jakarta;

2. Chaidirrozi Ash Shiddiq, 2002, Waterways, Balai Diklat APPD, Palembang.

3. DETEC (Dutch Environment Tecnology Consultant), 1998, The Study To Access Channel To The Port Of Banjarmasin, Final Report, Belanda.

4. Delft Hydraulics The Nederlands, Guidelines For The Design Of Inland Navigation Canals,Economic And Social Commission For Asia And The Pacific (ESCAP). 
5. Depdikbud, 1995, Kamus Besar Bahasa Indonesia (KBBI), BalaiPustaka,Jakarta

6. Konstruksi Kapal I ,2000, Balai Diklat APPD, Palembang.

7. Parlindungan Samosir, Drs, 1998, Teknik Pengerukan, Balai Diklat APPD, Palembang.

8. PIANC (Permanent International Association of Navigation Congresses), 1996, Bulletin No.91, Belgium.
9. Rekayasa Sungai, 2000, Balai Diklat APPD, Palembang.

10. Soedjono Kramadibrata, 1985, Perencanaan Pelabuhan, Ganeca Exact Bandung.

11. Undang-undang 21 Tahun 1992 Tentang Pelayaran

Tabel.1 Data Sarat Air Kapal yang berlayar di Sungai Musi Tahun 2007

\begin{tabular}{cccccccccccccc}
\hline Kategori & Ja & Fb & Mr & Ap & Me & Jn & Jl & Ag & Sp & Ok & No & De & $\boldsymbol{\Sigma}$ \\
\hline$\leq 1,0$ & 5 & 13 & 6 & 13 & 15 & 9 & 12 & 19 & 17 & 19 & 6 & 10 & 144 \\
$1,1-3,0$ & 111 & 92 & 108 & 89 & 80 & 92 & 90 & 115 & 115 & 113 & 93 & 90 & 1188 \\
$3,1-5,0$ & 105 & 142 & 165 & 137 & 133 & 108 & 132 & 166 & 129 & 149 & 118 & 121 & 1605 \\
$5,1-7,0$ & 62 & 50 & 54 & 65 & 77 & 67 & 64 & 78 & 72 & 79 & 71 & 70 & 809 \\
$7,1-9,0$ & 0 & 3 & 3 & 2 & 2 & 2 & 2 & 1 & 4 & 0 & 0 & 0 & 19 \\
\hline
\end{tabular}

Sumber : Administrator Pelabuhan Palembang

Tabel 2. Data Hidrografi Ambang Luar Sungai Musi Tahun 2006

\begin{tabular}{ccccccccccccc}
\hline & Jan & Feb & Mar & Apr & Mei & Jun & Jul & Aug & Sep & Okt & Nop & Des \\
\hline AT & 37 & 35 & 33 & 32 & 35 & 37 & 40 & 35 & 32 & 33 & 36 & 37 \\
AR & 4 & 6 & 9 & 7 & 5 & 4 & 4 & 5 & 9 & 7 & 4 & 1 \\
ATr & 30.13 & 29.48 & 29.03 & 29.53 & 30.45 & 31.73 & 32 & 30.39 & 28.03 & 28.80 & 30.63 & 31.70 \\
ARr & 8.61 & 12.72 & 10.74 & 11.1 & 9.58 & 11.16 & 8.3 & 9.96 & 11.56 & 10.96 & 7.96 & 7.29 \\
\hline
\end{tabular}

Sumber : Administrator Pelabuhan Palembang Ukuran skala dalam desimeter $(d m)$

Tabel 3 Dimensi Bagian Penampang Melintang Alur Pelayaran Sungai Musi Pada Lokasi Payung Selatan

\begin{tabular}{cllc}
\hline No. & \multicolumn{1}{c}{ Hasil Survey } & \multicolumn{1}{c}{ Besaran } & Satuan \\
\hline 1. & Lebar permukaan air $\left(\mathrm{b}_{\mathrm{w}}\right)$ & 559,149 & $\mathrm{~m}$ \\
2. & Luas penampang melintang $\left(\mathrm{A}_{\mathrm{c}}\right)$ & $5.419,882$ & $\mathrm{~m}^{2}$ \\
3. & Kecepatan pengaliran rata-rata $(\mathrm{u})$ & 0,54 & $\mathrm{~m} / \mathrm{det}$ \\
4. & Luas penampang kiri $\left(\mathrm{A}_{\mathrm{cl}}\right)$ & 2781,09 & $\mathrm{~m}^{2}$ \\
5. & Lebar penampang atas sebelahkiri $\left(\mathrm{bw}_{\mathrm{l}}\right)$ & 299,2686 & $\mathrm{~m}$ \\
6. & Luas penampang kanan $\left(\mathrm{A}_{\mathrm{cr}}\right)$ & 2601,702 & $\mathrm{~m}^{2}$ \\
7. & Lebar penampang atas sebelah kanan $\left(\mathrm{bw}_{\mathrm{r}}\right)$ & 259,88 & $\mathrm{~m}$ \\
\hline
\end{tabular}

Sumber:PT.(Persero) Rukindo Unit Usaha Palembang Tahun 2007

Tabel 4. Kandungan Jenis Material Alur Pelayaran Sungai Musi

\begin{tabular}{|l|l|c|c|}
\hline \multicolumn{1}{|c|}{ Lokasi } & \multicolumn{1}{c|}{ Jenis Material } & \multicolumn{2}{c|}{ Kandungan (\%) } \\
\cline { 3 - 4 } & & Lumpur & Pasir \\
\hline C1 & lumpur, pasir halus, pasir sedang, & 95 & 5 \\
& karang, lempung lunak & 95 & \\
Tanjung Carat & lumpur, lempung lunak, pasir,halus & 95 & 5 \\
Tanjung Buyut & lumpur, lempung lunak, pasir,halus & 95 & 5 \\
P. Utara & lumpur, lempung lunak, pasir, halus & 95 & 5 \\
P. Selatan & lumpur, lempung lunak, pasir,halus & 95 & 5 \\
Kramat Utara & lumpur, lempung lunak, pasir,halus & 90 & 10 \\
Parit XII & lumpur dan pasir halus & 100 & 0 \\
P. Ayam & lumpur & 85 & 15 \\
Selat Upang & lumpur dan pasir halus & 85 & 15 \\
Selat Jaran & pasir halus & 85 & 15 \\
Aer Kumbang & lumpur dan pasir sedang & 85 & 15 \\
\hline
\end{tabular}

Sumber : PT. Rukindo Unit Usaha Palembang Tahun 2007 
Tabel .8 Rekapitulasi Kurva Durasi Tahun 2007 Berdasarkan Data Hidrografi (+LWS)

\begin{tabular}{|c|c|c|c|c|c|c|c|c|c|c|c|c|c|c|}
\hline $\begin{array}{l}\text { h } \\
(\mathbf{d m})\end{array}$ & Jan & Feb & Mar & Apr & Mei & Juni & Juli & Agt & Sept & Okt & Nop & Des & Ttl & $\begin{array}{l}\% \\
\text { waktu }\end{array}$ \\
\hline 1 & 0 & 0 & 0 & 0 & 0 & 2 & 0 & 0 & 0 & 0 & 0 & 2 & 4 & 100,00 \\
\hline 2 & 6 & 0 & 0 & 0 & 3 & 10 & 9 & 0 & 0 & 8 & 1 & 16 & 53 & 99,955 \\
\hline 3 & 13 & 0 & 0 & 1 & 6 & 14 & 12 & 2 & 0 & 11 & 10 & 16 & 85 & 99,353 \\
\hline 4 & 8 & 6 & 0 & 4 & 15 & 10 & 14 & 4 & 14 & 12 & 15 & 18 & 120 & 98,388 \\
\hline 5 & 17 & 11 & 0 & 10 & 9 & 14 & 21 & 14 & 13 & 13 & 18 & 18 & 158 & 97,025 \\
\hline 6 & 14 & 22 & 5 & 17 & 17 & 16 & 18 & 19 & 14 & 16 & 14 & 17 & 189 & 95,232 \\
\hline 7 & 14 & 16 & 19 & 19 & 15 & 20 & 26 & 21 & 17 & 9 & 17 & 18 & 211 & 93,086 \\
\hline 8 & 19 & 22 & 22 & 26 & 18 & 23 & 23 & 28 & 18 & 21 & 21 & 20 & 261 & 90,690 \\
\hline 9 & 19 & 25 & 21 & 10 & 10 & 16 & 18 & 20 & 22 & 19 & 16 & 16 & 212 & 87,727 \\
\hline 10 & 18 & 19 & 33 & 24 & 23 & 26 & 27 & 23 & 18 & 11 & 22 & 18 & 262 & 85,320 \\
\hline 11 & 20 & 33 & 24 & 19 & 19 & 25 & 28 & 26 & 23 & 23 & 21 & 28 & 289 & 82,346 \\
\hline 12 & 21 & 26 & 34 & 32 & 26 & 27 & 27 & 29 & 18 & 31 & 29 & 24 & 324 & 79,064 \\
\hline 13 & 31 & 18 & 28 & 25 & 33 & 28 & 24 & 29 & 25 & 26 & 31 & 30 & 328 & 75,386 \\
\hline 14 & 30 & 22 & 35 & 28 & 34 & 28 & 34 & 27 & 23 & 27 & 29 & 30 & 347 & 71,662 \\
\hline 15 & 50 & 42 & 24 & 44 & 29 & 23 & 45 & 27 & 36 & 42 & 25 & 26 & 413 & 67,723 \\
\hline 16 & 26 & 32 & 55 & 46 & 37 & 25 & 38 & 26 & 26 & 39 & 27 & 26 & 403 & 63,034 \\
\hline 17 & 32 & 38 & 37 & 44 & 48 & 20 & 26 & 35 & 25 & 32 & 29 & 16 & 382 & 58,458 \\
\hline 18 & 24 & 42 & 53 & 39 & 42 & 26 & 37 & 29 & 38 & 24 & 55 & 38 & 447 & 54,121 \\
\hline 19 & 40 & 31 & 35 & 25 & 33 & 28 & 23 & 23 & 31 & 28 & 18 & 17 & 332 & 49,046 \\
\hline 20 & 31 & 34 & 44 & 39 & 26 & 41 & 32 & 35 & 18 & 41 & 33 & 39 & 413 & 45,277 \\
\hline 21 & 40 & 22 & 26 & 25 & 34 & 19 & 26 & 27 & 22 & 30 & 25 & 25 & 321 & 40,588 \\
\hline 22 & 32 & 22 & 26 & 26 & 22 & 18 & 17 & 30 & 20 & 33 & 21 & 22 & 289 & 36,944 \\
\hline 23 & 31 & 25 & 26 & 25 & 20 & 19 & 24 & 23 & 18 & 24 & 22 & 23 & 280 & 33,663 \\
\hline 24 & 14 & 20 & 22 & 20 & 27 & 20 & 22 & 23 & 24 & 27 & 21 & 21 & 261 & 30,484 \\
\hline 25 & 26 & 18 & 20 & 23 & 18 & 26 & 19 & 28 & 23 & 20 & 13 & 23 & 257 & 27,520 \\
\hline 26 & 20 & 24 & 23 & 23 & 14 & 17 & 17 & 15 & 25 & 19 & 18 & 19 & 234 & 24,603 \\
\hline 27 & 23 & 33 & 18 & 19 & 26 & 24 & 11 & 27 & 13 & 15 & 21 & 18 & 248 & 21,946 \\
\hline 28 & 12 & 8 & 28 & 15 & 11 & 22 & 17 & 18 & 22 & 19 & 25 & 19 & 216 & 19,130 \\
\hline 29 & 12 & 11 & 15 & 10 & 19 & 15 & 9 & 23 & 25 & 19 & 12 & 12 & 182 & 16,678 \\
\hline 30 & 13 & 17 & 20 & 20 & 21 & 16 & 16 & 17 & 19 & 10 & 14 & 12 & 195 & 14,612 \\
\hline 31 & 19 & 8 & 11 & 19 & 17 & 11 & 12 & 16 & 24 & 19 & 20 & 14 & 190 & 12,398 \\
\hline 32 & 11 & 12 & 13 & 18 & 18 & 19 & 9 & 16 & 15 & 11 & 13 & 17 & 172 & 10,241 \\
\hline 33 & 8 & 13 & 13 & 14 & 15 & 14 & 15 & 15 & 15 & 11 & 15 & 14 & 162 & 8,288 \\
\hline 34 & 12 & 8 & 8 & 6 & 9 & 10 & 14 & 18 & 22 & 12 & 18 & 10 & 147 & 6,449 \\
\hline 35 & 7 & 10 & 4 & 4 & 13 & 14 & 11 & 13 & 17 & 11 & 12 & 13 & 129 & 4,780 \\
\hline 36 & 12 & 6 & 0 & 1 & 11 & 9 & 6 & 10 & 18 & 9 & 10 & 14 & 106 & 3,315 \\
\hline 37 & 9 & 0 & 0 & 0 & 4 & 11 & 7 & 5 & 22 & 10 & 5 & 14 & 87 & 2,112 \\
\hline 38 & 10 & 0 & 2 & 0 & 2 & 11 & 7 & 2 & 21 & 5 & 4 & 14 & 78 & 1,124 \\
\hline 39 & 0 & 0 & 0 & 0 & 0 & 3 & 2 & 1 & 0 & 7 & 0 & 7 & 20 & 0,238 \\
\hline 40 & 0 & 0 & 0 & 0 & 0 & 0 & 1 & 0 & 0 & 0 & 0 & 0 & 1 & 0,011 \\
\hline
\end{tabular}

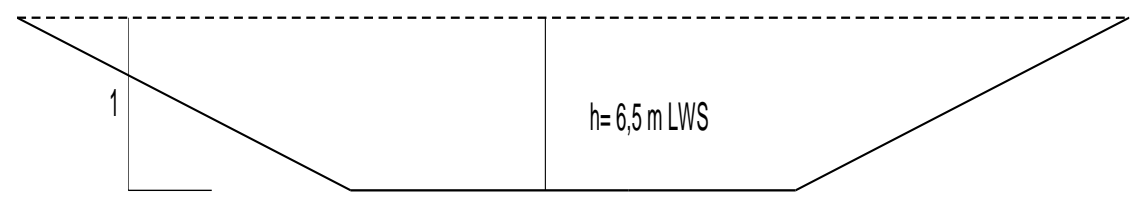

4

Lebar dasar alur $=120$ meter

Gambar 1. Penampang Melintang Alur Pelayaran Sungai Musi 
Tabel 9. Daftar Kecepatan Maksimum Berlayar Kapal, Nilai Kecepatan Arus Balik \& Tinggi Penurunan Muka Air Setiap Ukuran Kapal (DWT)

\begin{tabular}{ccccccc}
\hline & \multicolumn{2}{c}{ Batas Maksimum } & \multicolumn{4}{c}{ Batas Kritis } \\
\cline { 2 - 7 } Ukuran & \multicolumn{2}{c}{ Kecepatan Kapal } & \multicolumn{2}{c}{ Tinggi Penurunan } \\
Muka Air & \multicolumn{2}{c}{ Kec. Arus Balik } \\
\cline { 2 - 7 } Kapal & $\mathrm{Vs}$ & $\mathrm{Vs}$ & $\Delta \mathrm{h}^{\wedge} \mathrm{r}$ & $\Delta \mathrm{h}^{\wedge}$ & $\Delta \mathrm{V}_{\mathrm{r}}$ & $\Delta \mathrm{V}^{\wedge}{ }_{\mathrm{l}}$ \\
\hline DWT & $(\mathrm{m} / \mathrm{det})$ & $($ Knot $)$ & $(\mathrm{m})$ & $(\mathrm{m})$ & $(\mathrm{m} / \mathrm{det})$ & $(\mathrm{m} / \mathrm{det})$ \\
1000 & 5,033 & 9,783 & 0,118 & 0,115 & 0,2219 & 0,2219 \\
2000 & 4,756 & 9,245 & 0,112 & 0,103 & 0,22198 & 0,211 \\
3000 & 4,413 & 8,578 & 0,104 & 0,092 & 0,22195 & 0,202 \\
4000 & 4,116 & 8,001 & 0,097 & 0,084 & 0,2219 & 0,198 \\
5000 & 3,852 & 7,489 & 0,091 & 0,078 & 0,2218 & 0,1956 \\
6000 & 3,509 & 6,821 & 0,084 & 0,070 & 0,22195 & 0,193 \\
7000 & 3,317 & 6,448 & 0,0799 & 0,067 & 0,2219 & 0,192 \\
8000 & 3,131 & 6,086 & 0,075 & 0,066 & 0,2219 & 0,192 \\
9000 & 2,994 & 5,819 & 0,071 & 0,059 & 0,2219 & 0,191 \\
10.000 & 2,872 & 5,583 & 0,069 & 0,057 & 0,22195 & 0,190 \\
15.000 & 2,385 & 4,636 & 0,057 & 0,047 & 0,22195 & 0,189 \\
20.000 & 2,035 & 3,956 & 0,049 & 0,040 & 0,22196 & 0,188 \\
\hline
\end{tabular}

Sumber : Hasil Analisis

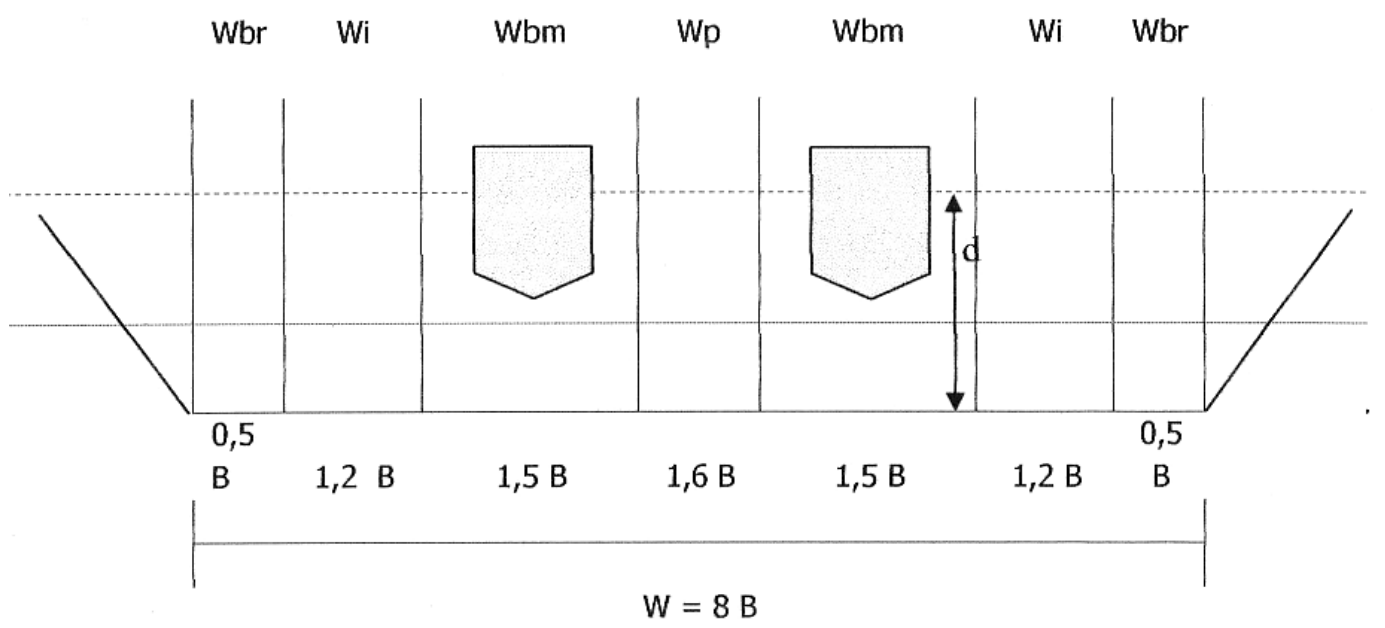

Gambar.3 Penampang Melintang Alur Pelayaran Yang Aman

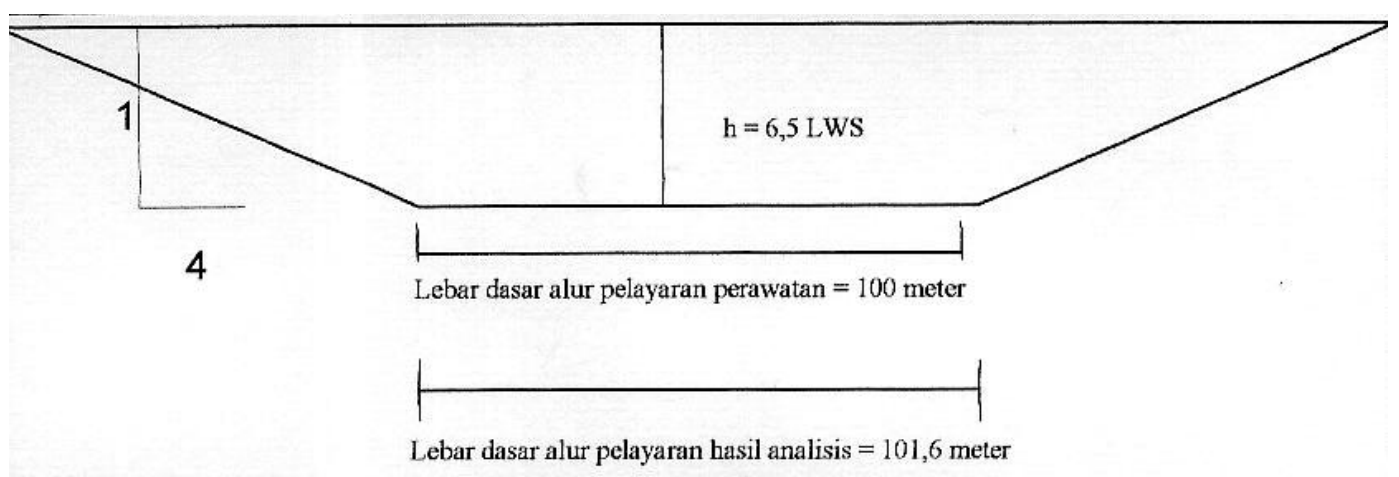

Gambar 4. Penampang Melintang Alur pelayaran yang aman 


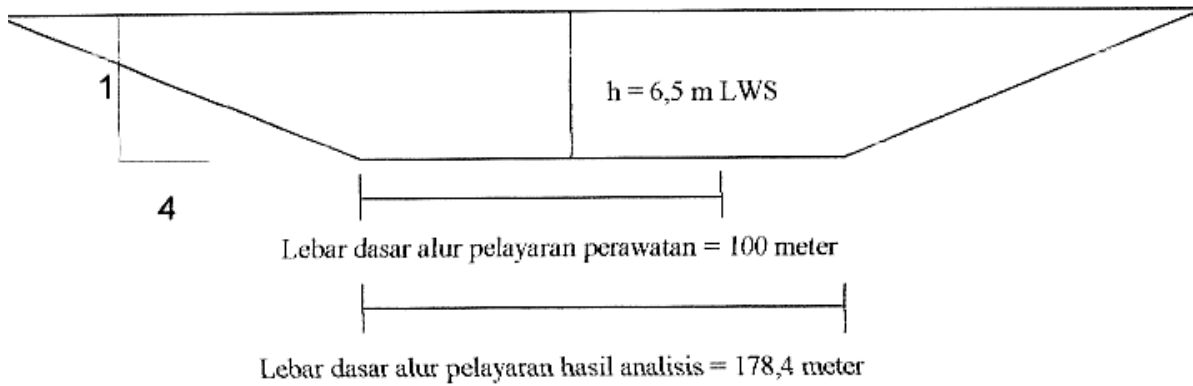

Gambar 5. Penampang melitang Alur Pelayaran Sungai Musi dengan Lebar Dasar Alur78,4 m. 